\title{
The Value of Tropical Biodiversity in Rural Melanesia
}

\author{
Simon Foale, Michelle Dyer and Jeff Kinch
}

\begin{abstract}
In this paper we discuss differences in the ways transnational conservationists and Melanesian farmers, hunters and fishers value 'biodiversity'. The money for conservation projects in developing countries originates from people who are embedded in a capitalist system, which allows engagement with nature as an abstract entity. Their western education has given them a scientific/ evolutionary-based worldview, which attributes intrinsic value to all species (and particular arrangements of species, e.g. rainforests and coral reefs), irrespective of economic value or ecosystem function. Because this value system is mostly not shared by the custodians of the biodiversity that conservationists want to save, alternative tactics and arguments are utilised. These inevitably take the form of so-called 'win-win' economic rationales for preserving biodiversity, most of which do not work well (e.g. bioprospecting, ecotourism, non-timber forest products, environmental certification schemes, payments for ecosystem services, etc.), for reasons which we detail. Agriculture- and aquaculture-based livelihoods appear to enjoy more success than the 'win-win' options but do not necessarily obviate or deter further biodiversity loss. Artisanal use of species-poor but productive and resilient pelagic fisheries is increasing. These ecological and economic realities bring into sharp focus the importance of understanding differences in value systems for successful biodiversity conservation in the tropics.
\end{abstract}

Key words: epistemology; worldview; poverty; conservation; education; development

Simon Foale (corresponding author), College of Arts, James Cook University, simon.foale@jcu.edu.au

Michelle Dyer, College of Arts, James Cook University, michelle.dyer1@my.jcu.edu.au

Jeff Kinch, PNG NFA National Fisheries College, jkinch@fisheries.gov.pg

(C) 2016 Authors

LiU Electronic Press, DOI 10.3384/VS.2001-5992.164111

http://valuationstudies.liu.se 


\section{Introduction}

This article explores the incomplete correspondence of economic (or 'utilitarian') and intrinsic (or 'inherent' or 'heritage') values of speciesrich tropical ecosystems in Melanesia 1 - coral reefs and rainforestsand the problems this poses for western conservationists on the one hand, and the people who own and use the resources provided by these ecosystems on the other. Following a detailed elaboration of what we mean by 'intrinsic' value, we argue three main points. First, that the intrinsic values of reefs and rainforests, and the numerous species they comprise, are particularly salient to people who subscribe to the crisis narrative of accelerated species extinction-a narrative contingent upon a belief in the theory of evolution and the concept of geological time. Second, that these beliefs are mostly not shared by the great majority of the people who own and use the reefs and rainforests in Melanesia. Third, that attempts by western environmentalists to retro-fit economic values to reefs and rainforests often fail because it is often possible for resource owners to achieve a similar or greater economic benefit from replacing substantial fractions (typically not all) of their species-rich natural ecosystems with species-poor (indeed in some cases monoculture) systems whose economic value is greater.

Additionally, western environmentalists' attempts to approach a clash of values by reframing their conservation arguments in terms of economic benefit often ignore complex political realities operating at multiple scales (Filer 2000, 2004, 2011a), affecting both the governance of natural resources and the delivery of the health and education services that are so notoriously lacking in most of Melanesia (West 2006). These realities include profound power inequities between urban educated elites and rural villagers as well as lingering antipathies among many different language (or 'ethnic') groups, which often lead to inequitable distribution of services as a result of cronyism, corruption and clientelism among national and provincial politicians. Finally we examine the logical implications of these value mismatches in terms of resource management and economic development policy.

\section{The Intrinsic Value of Rainforests and Coral Reefs and the Global Extinction Crisis}

The global extinction crisis is undoubtedly the most compelling narrative in the worldview of most modern transnational conservationists. While humans have caused large numbers of extinctions both prehistorically (Steadman 2006; Steadman et al.

\footnotetext{
${ }^{1}$ In this paper we use the term 'Melanesia' to broadly refer to Papua New Guinea (PNG), Solomon Islands, Vanuatu and Fiji. However, the overwhelming focus of our arguments here is on PNG and Solomon Islands, where the three of us have, between us, over 40 years' experience.
} 
2002) and historically, the current rate of species extinctions is considered to be 100-1000 times the natural rate (Rockstrom et al. 2009) - a rate of loss not seen since the last global mass extinction event.

Accelerated species loss is a problem in the minds of scientifically educated conservationists for two main reasons: (1) species have an intrinsic value which is lost forever when they become extinct, because they cannot simply re-evolve within a human lifetime (Adams 2004; Wilson 1992); (2) all biological species are part of a functionally interconnected ecosystem that delivers 'ecosystem goods and services', and the attrition of species reduces the capacity of ecosystems to deliver these goods and services (Hooper et al. 2005; Mora et al. 2011). For the purposes of this argument we are interested in the relative priority of these two aspects of the species loss problem in the minds and motivations of western conservationists (Foale 2001; Foale and Macintyre 2005), and how this plays out in conservation writing and policy implementation. We will discuss the second aspect further below.

A third aspect of the value of species is aesthetic. This is less commonly articulated in scientific literature but is very prominent in the publicity and fundraising material of conservation organizations (and many scientific agencies, university departments and centres), in the form of images of colourful or otherwise charismatic organisms (Foale and Macintyre 2005). Aesthetic aspects of species can be compellingly imbricated with intrinsic value for species that display spectacular evolutionary adaptations such as cryptic morphology (e.g. leafy sea dragons, pygmy seahorses and stick insects), warning colouration (e.g. nudibranchs and poison arrow frogs), or other features that show how perfectly the species is adapted to its environment. Images of organisms with these striking features tell a powerful story about evolution, and remind us of the long timescales involved in the processes of natural selection and adaptation.

The aesthetic value of coral reefs and their associated fauna is greatly enhanced by the fact that corals tend to grow best in warm, nutrient-poor, clear water, which makes them attractive places for recreational snorkelling and diving and thus more amenable to aesthetic consumption. People are more comfortable donning a diving mask in an environment where it is easy to see both the attractions and potential dangers. High water clarity and the fact that many reef creatures are brightly coloured (for reasons still poorly understood and not always explicable by evolutionary narratives such as warning colouration or sexual selection) means that photography is also relatively easy (Foale and Macintyre 2005), which in turn has greatly expanded the popularity of aesthetic consumption of coral reefs among affluent populations. The extent to which photographically mediated aesthetic fetishization of reef and rainforest organisms 


\section{Valuation Studies}

reinforces their scientific intrinsic value, which in turn influences (a) the emotional drivers of western environmentalist fervour (Milton 2002) and (b) the way conservation-related scientific studies are shaped and framed, which is particularly worthy of closer examination.

\section{Environmental Values of Rural Melanesia}

About half of the populations of Papua New Guinea (PNG) and Solomon Islands have no more than six years of primary education. In PNG, the average length of schooling received by people aged 25 years and older is 3.9 years, which is comparable with the Solomon Islands at 4.5 years (UNDP 2014). Thus, the great majority of the customary custodians of coral reefs and rainforests have not had the privilege of a scientific education to secondary, much less tertiary, level.

While most people are overtly Christian, many pre-Christian belief systems and associated cultural institutions persist, sometimes in tension with Christian beliefs (Jacka 2010; Robbins 1995, 2004). Regardless of the level of syncretism of Christian and pre-Christian cosmologies, most people (a) have never heard of the theory of evolution; (b) may have heard of it but are unlikely to understand or believe it; or (c) follow religious teachings that explicitly deny it. Below is some text from the Seventh Day Adventist (SDA) study school booklet developed by the Pacific branch of the worldwide SDA church. One of us (MD) witnessed this lesson being taught in church on the Sabbath (holy day of rest for SDA church on a Saturday) in a village in the Western Province of Solomon Islands:

'The earth is the Lord's' (Psalm 24:1.2).

A scientist once challenged the need for God. The scientist argued that he could create people just as well as any God could. God said; 'Okay, go ahead and do it.' The scientist began to gather some dirt. But God said, 'Wait a minute. Make your own dirt!'

Of course this story is not true. But the point is clear; God is the only one who can create from nothing. God made all the things of the universe. These include our world, things we own, our bodies. He is the legal owner of everything. ${ }^{2}$

Further discussion in the study booklet during this lesson specifically mentions Charles Darwin, declaring that he was wrong about evolution. The fundamental belief on which Seventh Day Adventism is built is that God created the world in six days and on the seventh day he rested. Thus Seventh Day Adventists keep the Sabbath holy as a day of rest, doing no work or cooking from sunset on a Friday to sunset on Saturday. This basic tenet of the SDA church is obviously highly

2 (Seventh Day Adventist Church 2013:39.) 
incompatible with the theory of evolution and the church explicitly teaches that the theory of evolution and 'scientists' in general are mistaken on this point. The following quote is by Ellen G. White, an early SDA church leader writing in 1890 and is taken from the same church service and lesson as the previous:

I have been warned that we shall have a continuing struggle. Science and religion will be opposed to each other. This is because limited men do not understand the power and greatness of God. These words of the Holy Bible were given to me, 'Even men from your own people will rise up and twist the truth. They want the believers to follow them'. (Acts 20:30 NIrV) (adapted from Ellen G. White, Medical Ministry, 98). ${ }^{3}$

While these examples are drawn specifically from Seventh Day Adventist teachings these views on evolution and the earth's creation stem from biblical teachings common to most Christian denominations. Consequently very few people are likely to share the epistemological premises that lead western scientists and conservationists to attribute intrinsic value to all species, and to problematize extinction for this reason.

However, religious teachings that deny evolution in favour of creationism are not necessarily contrary to a desire for biodiversity preservation. Strategic use of biblical text may be used to make a case for biodiversity conservation that credits God, not humans, with supreme knowledge and creation. Literature produced by a Solomon Island's indigenous conservation association links conservation buzzwords with certain tracts from the Bible. For example, Genesis 6:19 and $21^{4}$ is cited to show biblical support for conserving biodiversity, specifically that these biblical passages teach that 'It is important to make sure ALL God's creatures are taken care of; even the smallest insects. God was saying that biodiversity is good' (KIBCA n. d., emphasis in original). Ezra 9:12 and Proverbs 13:22 are cited to show biblical support for using resources sustainably, that 'Sustainable means using resources in a way that meets the needs of people in the present while still making sure there will be enough left in the future' (KIBCA n. d., emphasis in original).

For the indigenous conservation association, headed by three elders of the SDA Church, this tactic allows a denial of evolution to coexist with a need to preserve biodiversity. ${ }^{5}$ In this case, this reasoning was applied with a sincere belief in both religious doctrine and a need for

3 (Seventh Day Adventist Church 2013: 43.)

4 These and other Bible quotations used here are taken from The Holy Bible: New King James Version (1982), Nashville, TN: Thomas Nelson.

5 We are also aware of a local NGO in PNG that used this tactic. 
preservation of biodiversity, and not with cynical intent based on privileging scientific 'truth' while manipulating religious beliefs to further an environmentalist agenda. This epistemological 'loophole' highlights the fact that not all environmentalist concern stems from an evolutionary-based worldview. Many western environmentalists also 'love' nature for a range of reasons other than the intrinsic value of species (Milton 2002), and many of the pre-Darwinian colonial environmentalists written about by Richard Grove (Grove 1990, 1995) were concerned with more concrete problems such as the effect of aggressive logging practices on soil erosion, the microclimate of small islands, and the sustainability of valuable timber resources.

The environmental values of rural resource owners are also profoundly shaped by their close and continuous reliance on the land and coastal sea for food, income and cultural reproduction. There is comparatively little in the way of a service sector in PNG or Solomon Islands (tourism has a more noticeable contribution to livelihoods in Vanuatu and Fiji).

In PNG, 83 per cent of food energy consumed comes from locally grown foods, derived largely from village gardens (Bourke and Harwood 2009). For most rural Papua New Guineans and Solomon Islanders there are very few cash earning opportunities outside agriculture, forestry and fisheries. Over 87 per cent of all cash income earned by rural people in PNG is from the sale of food crops at informal fresh food markets, commodity export tree crops and betel nut (Allen et al. 2009). Subsistence values are fundamental to people's relationships to land in which value is ascribed according to use. Value in land and resources is either (a) direct-such as a particular species of tree used to make canoes or house posts; (b) for income earning potential-through marketing garden produce, agricultural commodities (copra, coffee, cocoa) or other harvested forest or sea resources; or (c) through opportunities presented by foreign investment, such as palm oil plantations, logging, mining, etc.

\section{Labour and the value of land}

The importance of labour to the creation and augmentation of the value of land is paramount throughout most of rural Melanesia. Whether this requires clearing the original forest or almost invariably modifying it in some way is not the relevant point for most rural landowners. The rights to land gained through the invested labour, and the value in land thereby created is the main point of interest, socially and politically.

Once a person expends labour on the land then their rights to that land are created or added to. This helps to explain what may seem, from the outside, landowners' seemingly irrational choices over resource use. For example, it may be abundantly clear to villagers that they will gain higher income and better environmental outcomes by 
using portable sawmills and engaging in sustainable forestry under an FSC (Forest Stewardship Council) model. This, however, involves input of labour and thus a level of business and social organization that is complicated and politically fraught. By contrast, when contracting a foreign logging company, negotiating power and distribution of benefits is most often controlled by a small group of men (Porter and Allen 2015), following an entrenched 'big man' model of leadership. While this results in sharing smaller profits among a larger group it inclusively reinforces the rights of the wider customary landowning group rather than creating exclusive interest by one group through the input of their labour. This also acts as a mechanism of maintaining social equality in the village (Dyer 2016). As one village leader said:

Logging in the Solomon Islands is not for development, it's something for wealth, to share and eat to celebrate, to drink some beer. When we do logging in the Solomons that's how we think. ${ }^{6}$

As is evident from the above example, the ways that labour affects the value of land, and the economic choices people make, are not only profoundly important but also complex, and socially and politically contingent. By and large people carefully weigh the value of expected returns from a given enterprise with labour input and often switch deftly between alternatives depending on a range of factors, including fluctuating market prices (Foale 2005). However, socially and politically informed analyses of the economic strategies of Melanesian landowners (Curry 1999; Macintyre and Foale 2004; Curry and Koczberski 2012, 2013; Curry et al. 2015) frequently contradict the 'rational actor' (or Homo economicus) models of decision making favoured by many environmental economists.

\section{Forests}

In most of Melanesia, forested land provides the majority of resources essential to survival. But as we argue in the section on Coral reefs, there are striking contrasts with the scientifically informed value system. 'Folk taxonomies' (i.e. indigenous systems for naming and classifying flora and fauna) of forest plants tend to be extensive and have a relatively high correspondence with scientific categories at the level of species (e.g. Henderson and Hancock 1988; Kwa'iloloa and Burt 2001; Panoff 1969; Peekel 1984; Schmid 1991). Bird and mammal folk taxa also tend to have relatively high levels of correspondence with scientific categories (Majnep and Bulmer 1977, 2007). However higher level folk taxonomic categories frequently depart dramatically from phylogeny-based classification systems (e.g. Bulmer 1967; Dwyer 1976). Folk classification systems can also be

6 See also Hviding (2015) for a similar anecdote. 
highly variable within a linguistic group, and subject to regular contestation (Sillitoe 2002).

As with some of the fish families on coral reefs (see below), speciesrich but economically unimportant groups of forest fauna, such as beetles, can often be taxonomically 'lumped' (Berlin et al. 1973; Bulmer 1982). Conversely, folk categories for varieties of domesticated plants are often highly elaborated. Most farmers can name a large number of varieties of key staples such as yams, taro, bananas and even sweet potato. Francoise Panoff (1969) recorded 129 named varieties of taro (Colocasia esculenta), 36 of bananas (Musa sapientum) and 37 of sugar cane (Saccharum officinarium) being cultivated by Mengen farmers (East New Britain, PNG) in the 1960s. A similarly rich proliferation of named varieties was found for the yam species Dioscorea alata and D. esculenta at Lihir in PNG (Macintyre and Foale 2013). Melanesian farmers have also enthusiastically adopted over 2200 varieties of 90 food crop species introduced in the post-colonial era (Bourke 2009). ${ }^{7}$

Nutritionally, forests are mainly used by rural Melanesians as places to practise swidden agriculture, given their capacity to return nutrients to soil during the fallow cycle. In other words, the primary value of forested land is for farming, a process that requires removing the forest and its associated biodiversity. The efficacy of the fallow cycle, where trees are allowed to take over a garden patch after it has produced staple food crops for two or three (rarely more) years, is primarily a function of time-ten years is usually ample; less than five is often insufficient. The longer the fallow period, the more nutrients are returned to the surface layers of soil (principally as leaf fall). In some areas farmers deliberately accelerate the fallow process by staking yam vines with cuttings of fast-growing deep-rooted species (e.g. Hibiscus tiliaceus). Fallow period is in turn a function of human population density (which is quite low in PNG and Solomon Islandsat 18 and 23 people $/ \mathrm{km}^{2}$ respectively ${ }^{8}$ - the fewer people who claim rights to a patch of forested land, the longer the average fallow cycle that is possible throughout that patch. According to Geertz (1969), the carrying capacity of forest bush fallow agricultural systems is at least one order of magnitude lower than that of the (pre-Green Revolution) wet rice systems of Southeast Asia.

Melanesian forests are also poor producers of protein, as evidenced by the fact that coastal people choose to obtain most of their protein from the sea, and that following the post-contact expansion of access

7 The South American sweet potato (Ipomea batatas), first introduced to PNG (via Indonesia) in the late 1600 s, accounted for $63.57 \%$ of PNG's total food crop production (by weight) in 2000 (Bourke et al. 2009).

${ }^{8}$ However, much higher densities can be found in places, particularly on many small islands. Foale et al (2011) provide maps showing coastal population densities in both PNG and Solomon Islands. 
to tinned fish and tinned meat in the PNG highlands, the nutrition of those populations improved measurably (Dennett and Connell 1988).

While traditional medicines derived from forests are still in frequent usage, many, if not the great majority, of traditional medicines that are still in use are planted around villages or sourced from roadsides or in regrowth areas. Modern medicines such as antibiotics, antiseptics and antimalarials, along with immunization, clean drinking water, improved sanitation and human waste disposal-have dramatically improved rural health levels. This is evidenced most clearly by the almost exponential increase in human populations since these medicines and lifestyle changes were introduced in the early to mid-twentieth century (Bennett 1987; Caldwell et al. 2001; Denoon 1997).

A similar argument can be made in relation to the use of forest biodiversity for traditional housing. Apart from the fact that so-called 'permanent' houses, made from sawn timber and corrugated iron roofs, are almost universally preferred (Macintyre and Foale 2004), many if not most of the materials used to construct traditional houses are sourced from domesticated or semi-domesticated species: sago, bamboo, black palm, betel nut palm, pandanus and coconut. People who live in close proximity to forests naturally obtain much of their housing material from them, but this does not mean that alternatives do not exist. Polynesian and Micronesian people living on coral atolls across the Pacific have been able to construct robust dwellings from the extremely depauperate flora of those environments. Many of the traditional houses on Tikopia, a remote and tiny high island with a profoundly humanized terrestrial ecosystem (Kirch 1997; Kirch and Yen 1982) were able to withstand $370 \mathrm{~km} / \mathrm{h}$ winds of Category 5 Cyclone Zoe in December 2002, an outcome more attributable to their ingenious and highly adapted engineering knowledge than to Tikopia's biodiversity.

The ongoing conundrum represented by Melanesian forests is that the market value of the timber extracted from them by transnational corporations is rarely converted to any significant improvement in the long-term wellbeing and human development of the traditional custodians (Allen 2011; Bennett 2000; Filer and Sekhran 1998; Hviding 2015; Hviding and Bayliss-Smith 2000). Industrial logging remains an environmental and economic tragedy because the allure of the (inevitably ephemeral) cash windfall it generates appears to be so irresistibly economically and socially expedient.

Forest conservation projects promoted on the basis of economic return cannot compete with the simplicity of the 'neo-bigman model' (Moore 2008), offered since at least the 1980s by large-scale logging companies. Alternatives to large-scale logging such as eco- 
tourism, FSC certified sawmilling, REDD $+{ }^{9}$ programmes and other alternative livelihood projects often lack implementation plans practical to village politics and the complications of customary land tenure (McDougall 2005). They mistakenly assume a communal business structure exists within the village community (Schoeffel 1997) and/or are difficult to sustain without outside input or expertise, especially in initial phases (Gegeo and Watson-Gegeo 2002). By contrast commercial activities carried out by a foreign logging company, for example, only require people to sign a piece of paper. This money is seen as 'free' money even though people are aware of the negative consequences-environmental and social-of such activity (Dyer 2016). Additionally, capturing financial benefit from such projects is most easily achieved by the more highly educated urban dwelling community or tribal members who will facilitate negotiations and who do not depend for their livelihoods on the land and resources to be exploited. ${ }^{10}$

Prior to 2004, most forestry leases in PNG and Solomon Islands did not extinguish local sovereignty over the land on which the logging took place, thus guaranteeing continued use for agriculture. This meant that, short of catastrophic soil loss from erosion, food security was not seriously threatened. This fact, combined with the cash windfall (albeit ephemeral) received as royalties for village dwelling landowners, the larger amounts received by those directly involved in negotiations with the companies (usually the educated elite) and the importance of this revenue for governments, has no doubt contributed to the high rate of sign-on to logging deals (see also Kinch 2006: 2831). Since 2004 in PNG, however, the advent of Special Agricultural and Business Leases or SABLs (Filer 2014; Nelson et al. 2014) poses a greater potential threat to customary land rights and associated food security.

\section{Coral reefs}

The lack of salience of species belonging to the most species-rich groups of organisms on coral reefs (for example corals (494 species in

9 The United Nations Collaborative Programme on Reducing Emissions from Deforestation and forest Degradation in developing countries. "REDD+ goes beyond deforestation and forest degradation, and includes the role of conservation, sustainable management of forests and enhancement of forest carbon stocks" (http:// www.un-redd.org).

10 There is a long history of involvement of Solomon Islander national politicians, including prime ministers, with companies that contract foreign logging companies. These Solomon Island owned companies are often granted 100\% tax exemptions and have been (and are) accused of illegal logging activity. A recent example is Minister for Forestry and Research, Heinz Horst Bodo Dettke (re-elected November 2015). Detke is $60 \%$ owner of Success Company Ltd, a company currently involved in a legal dispute over illegal logging above $400 \mathrm{~m}$ altitude on Kolombangara Island (http://www.abc.net.au/news/2015-02-16/solomon-islands-landowners-challengelogging-approval-kolombanga/6091994). 
Solomon Islands and 418 in Milne Bay, PNG (Allen et al. 2003; Green et al. 2006)); damselfishes (100 species); and gobies (120 species)) is reflected in the small number of names for these organisms in local languages. For example, in PNG and Solomon Islands, there are typically fewer than a dozen folk categories for corals (Foale 1998; Hviding 2005; Levinson 2008; Osmond et al. 2003; Ross et al. 2011), and less than a quarter as many folk categories for small reef fish as there are scientific species (Cohen et al. 2014; Foale 1998; Goto 1996; Hviding 2005; Ross et al. 2011). The word for coral in the lingua francas (Tok Pisin and Solomon Pijin) of PNG and Solomon Islands (ston) simply means 'stone'. ${ }^{11}$

Turtles have been the subject of intensive international conservation campaigns in Melanesia, where people traditionally harvest them with alacrity. Turtles have high economic and prestige value, and it is understandably difficult for local people to perceive the spatial and temporal scale of stock-replacement processes in such a highly mobile, slow-growing and long-lived species (Benson et al. 2011), and consequently the impacts that unrestrained harvesting can have on population viability over the long term. In Solomon Islands and PNG, Hawksbill turtle (Eretmochelys imbricata) populations were decimated in the nineteenth and early twentieth centuries as a result of the high demand for their shells internationally (Bennett 1987; Kinch and Burgess 2009), including from other Pacific Island groups (Shineberg 1966).

Most coastal people in Melanesia attribute relatively high economic/utility value to the species they commonly eat and sell, and their sense of agency in relation to populations of a small subset of high prestige-value species (mostly those which are traded or sold for cash) is embodied in tenure systems and other cultural institutions that restrict access to space, gear and species. Debates over the extent to which this sense of agency equates to a traditional conservation ethic have been reviewed by Foale et al. (2011) for Melanesia and the Pacific and by Davis and Ruddle (2010) more generally. Both argue for more socially informed analyses of these institutions than functionalist approaches (e.g. Berkes 1999; Berkes et al. 2000; Johannes 1978), which, though empirically weak, remain popular with many conservationists. ${ }^{12}$

Traditionally in some parts of Melanesia, a number of species were made taboo for particular groups of people, and in some cases only at certain times, due to their totemic status, or other beliefs about the

11 This also applies to many vernaculars (Ross et al. 2011), including the Misima language in Milne Bay, PNG, where the term nali, meaning 'stone', also glosses for all hard corals.

12 See also Bulmer (1982), Polunin (1984), Carrier (1987) and Foale and Manele (2004). 
effects of eating them. However even the functionalists (e.g. Johannes 1978) discount any significant conservation value of these institutions, mainly due to the small number of species to which they apply. Many beliefs and practices which come under the gloss 'totemic' have diminished or completely vanished across most of the Pacific.

\section{Retro-Fitting Ecosystem Goods and Service Values to Intrinsic Values}

Environmentalist groups appear to have tacitly understood for some time that the custodians of biodiverse ecosystems in various parts of the world do not share their Darwinian-Linnaean worldview that reifies the intrinsic/heritage value of species. An understandably common response to this has been to find ways of commoditizing species and ecosystems to use in arguing for their preservation. This approach includes the well-established ecosystem services (ES) approach of environmental economists (Costanza and Daly 1992; Costanza et al. 1997). In this section we examine and critique some of the ways this logic has been used in the case of coral reefs and rainforests in Melanesia.

\section{Alternative income quick fixes}

In Melanesia, bioprospecting and ecotourism have long been important platforms of the nature-as-commodity approach. For various reasons, neither of these options has provided, or is likely to provide, significant financial benefits for rural people in PNG or Solomon Islands, particularly compared to extractive industries and development aid (Gay 2009). In the case of bioprospecting, effective systems for equitably distributing any royalties from new drug discoveries have never been found, apart from the well-publicized case of a single village in Samoa (Cox 2001), and it is often possible to cheaply synthesize many compounds once discovered and characterized. Tourism suffers from lack of transport and infrastructure, and tourist fears of high crime levels (especially in the capital cities) and infectious diseases (see Foale, 2001; Filer, 2011a).

\section{Coral reef fisheries and food security}

Fish (harvested for food and income) is an ecosystem service provided by coral reefs that is increasingly used to justify transnational marine biodiversity conservation interventions. The following statement on the home page of the Coral Triangle Initiative exemplifies:

These unparalleled marine and coastal living resources provide significant benefits to the approximately 363 million people who reside in the Coral Triangle, as well as billions more outside the region. As a source of food, income and protection from severe weather events, the ongoing health of these ecosystems is critical. ${ }^{13}$

\footnotetext{
13 http://www.coraltriangleinitiative.org/about-us, accessed 27 March 2016 .
} 
In a somewhat more sober analysis, Teh et al. (2013) estimate that around six million people worldwide fish on coral reefs, and around three million of those live in Southeast Asia. Teh et al. (2013) also find that in the Western Pacific, coral reefs supply approximately 14 per cent of the total value of landed fish. Most of the rest of that value is represented by industrial tuna landings, the rent from which accrues almost entirely to national governments.

While healthy coral reefs provide complex topographic structures that can support a large standing stock of reef fish in the absence of fishing, the actual production rate of reef-associated fish is generally quite slow (Birkeland 1997; Russ and Alcala 2010). This is because corals are uniquely adapted to low-nutrient conditions (the same conditions that produce the plankton-free water clarity so coveted by diving tourists) and the rate of conversion of coral primary production to fishery production is very low. In contrast, high levels of productivity of a comparatively small suite of non-coral-dependent pelagic fish species (including sardines, scads, mackerels and tunas) are frequently found in waters enriched by nutrient-laden upwellings (Ruddle and Ishige 2005; Villanoy et al. 2011) and terrestrial run-off (Gehrke 2007; Oczkowski et al. 2009; Weng and Sibert 1997).

In Langalanga Lagoon, Solomon Islands, high human population and market pressures, combined with destructive fishing practices, have led to declining catch-per-unit-effort (CPUE) of reef fish species associated with a $22 \mathrm{~km}$ barrier reef enclosing the lagoon (Sulu et al. 2015). In response to this, many Langalanga fishers have, over the past three decades, switched to targeting fast growing, short-lived, small pelagic fish (sardines and scads) in reef passages at night, using lights and gill nets. Their mean CPUE for this new fishery is between two and five times the CPUE of reef fisheries, including relatively lightly fished reefs in other parts of the region (Roeger et al. 2016; Roeger 2013). Fishers interviewed by Roeger et al. (2016) claimed that the small pelagic fishery was not only higher yielding than the reef-fish fishery but also showed no sign of decline. There are many indications that as human populations and market pressures increase, coastal people in Melanesia will increasingly shift fishing effort away from species-rich, but low-productivity reef-associated fisheries to highproductivity pelagic fisheries comprised of a handful of species (Albert et al. 2014; Albert et al. 2015a).

In the Philippines and parts of Indonesia, where human population densities are between one and two orders of magnitude higher than they are in Melanesia, small pelagic fisheries have been intensively fished for several decades (Dalzell and Pauly 1990; Dalzell et al. 1990; Dalzell and Ganaden 1987). Although small pelagic fisheries have been fished to capacity or are already overfished in the Philippines (Dalzell and Ganaden 1987) and the Java Sea (Cardinale et al. 2011), their contribution to both income and food security throughout much of 


\section{Valuation Studies}

Southeast Asia, including the 'Coral Triangle', substantially outweighs that of reef fisheries (Dalzell et al. 1990; DABFAR 2014). By making comparisons of the productivity of these very different fisheries we do not intend to imply that coral reef fisheries do not provide significant benefits for some groups of coastal Melanesian people (Albert et al. $2015 \mathrm{~b}$ ) nor do we imply that reefs and their associated resources should not be managed. But the crisis narrative that a failure to protect coral reefs will lead to critical food shortages for large numbers of people does appear to be motivated more by an a priori concern for the intrinsic values of coral reefs than by their actual importance as an irreplaceable food supply.

\section{Forests versus oil palm}

Once forests have been logged and the timber sold (and the windfall spent), replacement with oil palm plantations has in some cases been a more economically beneficial option for significant numbers of local people than resuming farming and waiting for the forest to regrow. The nucleus estate oil palm model already established in PNG and Solomon Islands during the late colonial period generates incomes that allow large numbers of rural landowners to send children to school ${ }^{14}$ and achieve a far higher standard of living than they could with traditional farming (Koczberski and Curry 2005; Koczberski et al. 2012). In West New Britain in PNG, many smallholders also make food gardens on a portion of their land, thus maintaining a level of food security in addition to the oil palm-generated income (Koczberski et al. 2012). ${ }^{15}$ It is clearly problematic for people from rich countries that have already built much of their affluence through forestry and industrial farming and fishing, to expect rural villagers in poor countries not to want to do the same, by appealing to a set of scientific values they do not share.

\section{Policy Implications}

Many rural Papua New Guineans and Solomon Islanders continue to have a high level of control over their customary land and seas, though this is now being seriously threatened in some parts of PNG (Filer 2011b, 2014; Nelson et al. 2014). But they are unlikely to embrace the intrinsic value of species living in their biodiverse rainforests and reefs if these species are not of significant economic or utilitarian value to them. Additionally the opportunity cost of conservation may be high,

\footnotetext{
${ }^{14}$ The PNG Government started rolling out its universal free education programme around 2011, though some smallholder oil palm schemes have been in existence since the late 1960s.

${ }^{15}$ However more recent oil palm developments under the Special Agricultural and Business Lease (SABL) model appear far less beneficial to local landowners (Gabriel and Wood 2015; Nelson et al. 2014).
} 
given the paucity of government service provision and the availability of more lucrative, though environmentally destructive, economic alternatives.

It is unlikely that any of the great conservation thinkers of the West needed to worry about earning sufficient income to pay for their children's education and health care, or indeed where their next meal was coming from (Adams 2004; Chapin 2004; Dowie 2011). Would rural Melanesian land and reef owners transform into instant conservationists if they were all miraculously given access to tertiarylevel evolutionary biology courses? There are several other ontological factors that determine the extent to which we are able to prioritize the intrinsic value of species, wealth being perhaps the most important. There are very few conservationists who do not also enjoy disposable incomes and significant amounts of leisure time. ${ }^{16}$ The creation of a modern conservationist worldview requires not just acceptance of the evolutionary paradigm, but also a cocoon of affluence that affords a sense of separation from nature, and thus the capacity to objectify and idealize it (Chapin 2004; Ingold 1993). Is it possible for a population of economically marginalized farmers, hunters and fishers in the Solomon Islands and PNG, countries ranked by the UNDP as equal 157th out of 187 on the Human Development Index, to acquire the affluence and education levels of conservationists without first destroying the biodiversity the conservationists wish them to value? Are development and conservation compatible (Filer 1994; Filer 2004; Keppel et al. 2012; Kinch 2010; McShane et al. 2011; Helden 1998; West 2006)? The imperatives of economic development that dictate transforming the natural environment and social relations into 'fictitious commodities' (i.e. nature into resources, and exchange into labour, respectively: Polanyi 1944; Rist 2007) are at once inimical to the environmentalist agenda while being simultaneously employed by conservation organizations (Igoe and Brockington 2007).

While the mandate for continued economic growth in affluent countries lacks legitimacy (Jackson 2009; Raworth 2012; Wilkinson and Pickett 2009), growth can potentially provide much needed increases in human development indicators (particularly education) and standards of living in Melanesia. This in turn could potentially facilitate some level of flourishing of the same set of values that

16 Religious denomination and political leanings are also important factors. Although a recent Auspol survey (Wyatt and Stolper 2013) showed that, in Australia, agreement with the statement 'Evolution is currently occurring' was higher for university educated respondents $(78 \%)$ than for those with a high school education $(63 \%)$, a Pew Research Centre survey in the USA (2013) showed that significantly fewer Republican voters (21\%) believe in evolution (due to natural processes) than Democrat voters $(37 \%)$. The Pew survey also showed that fewer white evangelical Protestants $(8 \%)$ believe in evolution by natural processes than white 'mainline' Protestants (36\%) or 'unaffiliated' $(57 \%)$. 
motivate western conservationists. We can already see a microcosm of this potentiality among the small number of highly educated and relatively affluent Melanesians who have become dedicated conservationists. But with economies that are dominated by transnational primary resource extractors, and stubbornly high levels of corruption, corporate tax avoidance and capital flight (McKenzie and Baker 2014; McKenzie et al. 2015; Mousseau and Lau 2015), economic growth at present is not only slow, but always seems inevitably to be at the expense of forest and fisheries resources.

Mining, if adequately governed, has at least the potential to deliver significant economic benefits, though the contemporary reality is dominated by many negative social and economic impacts (Baines 2015; Filer and Macintyre 2006). Despite producing massive cash flows, mining appears to have largely failed to do much to alleviate poverty and improve service delivery in PNG (Johnson 2012).

There are many structural difficulties with local, provincial and even national governance institutions that seem to systematically stymie adequate resourcing of education and health. These problems have at least some of their roots in the deep cultural and political divisions that PNG and Solomon Islands inherited when their boundaries were demarcated by former colonial powers, and are unlikely to be solved quickly (Barclay and Kinch 2013; Firth 2006). There is nevertheless much that relatively powerful countries such as Australia can do to stem the immense financial haemorrhaging from Solomon Islands and PNG through tax and export/import duty evasion (Allen 2011; Henry 2012; Mousseau and Lau 2015; Shaxson $2011)^{17}$ and other forms of illicit financial flows (Palmer 2015). Greater control over, and transparency of, foreign investment in Australian real estate would make it harder for corrupt Melanesian politicians and officials to hide bribe money and other illicit financial flows. Bilateral investment in well-structured institutional reforms to resource ministries could also go a long way to reducing the huge national losses resulting from corrupt dealings with transnational resource extractors. This would enable more complete capture of the economic rent from exported commodities, which could in turn be invested in chronically resource-starved education and health ministries.

\section{Conclusion}

Ultimately, those of us who worry about biodiversity loss anywhere need to work harder at finding ways of (a) making those with the heaviest ecological footprint bear more of the cost of saving it, and (b) improving economic and human development in poor countries (Raworth 2012). This means moving beyond the neoliberal solutions

17 Shaxson (2011) estimates that, around the so-called 'developing world', for every dollar of aid money that flows in, ten flow out as capital flight, due to, among other things, transfer mispricing of exported commodities and the use of financial secrecy jurisdictions (aka tax havens) by transnational corporations. 
long favoured by big environmental non-governmental organizations (NGOs) (Büscher et al. 2012; Igoe and Brockington 2007), which rarely frame environmental destruction or economic inequality in terms of structural violence (Cole 2012; Farmer 2004), or try to confront the global-scale drivers of poverty outlined above. Instead they typically place most of the economic burden of conservation on rural farmers and fishers. These predominantly locally based measures too often constitute some form of austerity for people whose lives are already patently austere. Where so-called win-win solutions are proposed, they frequently embody the same logics of commoditization of both nature and social relations that fan the flames of consumerism and possessive individualism (Foster 2005; Hickel and Khan 2012; Macpherson 1962; Martin 2007), and in turn environmental destruction.

To more effectively proselytize the intrinsic, heritage value of biodiversity to the present-day custodians of Melanesia's tropical rainforests and coral reefs would require, at the very least, a serious commitment to equitable delivery of bottom-up, quality education services by adequately resourcing them. This in turn will require engaging with, among other things, the political economy of transnational resource piracy and the crony capitalist regimes that dominate the economies and manipulate the governments of these countries. It would be encouraging to see the conservation community taking a greater interest in combatting capital flight, including the role of governments of wealthy countries in condoning and legitimating the financial secrecy systems that facilitate it. There are many other compelling and culturally well-informed ideas for addressing the complex and formidable challenge of improving economic and human development in Melanesia ${ }^{18}$ that also transcend the neoliberal solutions we critique above, but which space precludes discussion of here.

We conclude that a better understanding of the cultural, economic and historical underpinnings of the fundamental differences between the environmental worldviews of rural Melanesian farmer-fishers and transnational conservationists should lead to more epistemologically aware and less hubristic approaches to biodiversity conservation. Deterministic thinking about the relationship between biodiversity and ecosystem services risks producing project dependency and/or damaging the credibility of otherwise well-meaning interventions and interveners. We also hope that our argument stimulates a greater interest in and commitment to tackling some of the more egregious global drivers of poverty, inequality and underdevelopment in the region.

18 (Allen 2013; Curry and Koczberski 2013; Jolly et al. 2012; Macintyre 2008, 2011, 2012; McCormack and Barclay 2013; Patterson and Macintyre 2011). 
Acknowledgments. We thank Dr Gina Koczberski for many constructive comments on an earlier draft of this paper, and two anonymous reviewers for useful suggestions and constructive criticism. This paper originated as a talk presented at a conference titled 'Values of Dominance', organized and funded by Dr Steffen Dalsgaard and Professor Ton Otto in Cairns in December 2012. We thank them both for their support, advice and encouragement.

\section{References}

Adams, William M. 2004. Against Extinction: The Story of Conservation. London: Earthscan.

Albert, Joelle A., Doug Beare, Anee-Maree Schwarz, Simon Albert, Regon Warren, James Teri, Faye Siota, and Neil L. Andrew. 2014. "The Contribution of Nearshore Fish Aggregating Devices (FADs) to Food Security and Livelihoods in Solomon Islands." Plos One 9(12). doi: 10.1371/journal.pone.0115386.

Albert, Simon, Shankar Aswani, Paul L. Fisher, and Joelle Albert. 2015a. "Keeping Food on the Table: Human Responses and Changing Coastal Fisheries in Solomon Islands." Plos One 10(7). doi: 10.1371/ journal.pone.0130800.

Albert, Joelle A., Andrew D. Olds, Simon Albert, Annabelle Cruz-Trinidad, and Anne-Maree Schwarz. 2015b. "Reaping the Reef: Provisioning Services from Coral Reefs in Solomon Islands.” Marine Policy 62: 244251.

Allen, Mark, Jeff Kinch, and Tim Werner. 2003. "Living Coral Reef Resources of Milne Bay Province, Papua New Guinea." In A Rapid Marine Biodiversity Assessment of Milne Bay Province, Papua New Guinea-Survey II (2000), edited by Gerald R. Allen, Jeff Kinch, Sheila A. McKenna and Pamela Seeto, 56-74. Washington, DC: Conservation International.

Allen, Matthew. 2011. "The Political Economy of Logging in Solomon Islands." In The Political Economy of Economic Reform in the Pacific, edited by Ron Duncan, 277-302. Manila: Asian Development Bank.

—. 2013. "Melanesia's Violent Environments: Towards a Political Ecology of Conflict in the Western Pacific." Geoforum 44: 152-161.

Allen, Matthew G., R. Michael Bourke, and Andrew McGregor. 2009. "Cash Income from Agriculture." In Food and Agriculture in Papua New Guinea, 283-424. Canberra, ACT: ANU E Press.

Baines, Graham. 2015. "Solomon Islands is Unprepared to Manage a Minerals-Based Economy." State, Society and Governance in Melanesia Discussion Paper, Australian National University 2015/6:20.

Barclay, Kate, and Jeff Kinch. 2013. "Local Capitalisms and Sustainability in Coastal Fisheries: Cases from Papua New Guinea and the Solomon Islands." In Engaging with Capitalism: Cases from Oceania, edited by Fiona McCormack and Kate Barclay, 107-138. Bingley, UK: Emerald. 
Bennett, Judith A. 1987. Wealth of the Solomons. A History of a Pacific Archipelago, 1800-1978. Honolulu: University of Hawaii Press.

- 2000. Pacific Forest: A History of Resource Control and Contest in Solomon Islands, c. 1800-1997. Cambridge: The White Horse Press.

Benson, Scott R., Tomoharu Eguchi, Dave G. Foley, Karin A. Forney, Helen Bailey, Creusa Hitipeuw, Betuel P. Samber, Ricardo F. Tapilatu, Vagi Rei, Peter Ramohia, John Pita, and Peter H. Dutton. 2011. "Large-Scale Movements And High-Use Areas of Western Pacific Leatherback Turtles, Dermochelys Coriacea." Ecosphere 2(7): 84.

Berkes, Fikret. 1999. Sacred Ecology: Traditional Ecological Knowledge and Resource Management. Philadelphia, PA: Taylor and Francis.

Berkes, Fikret, Johan Colding, and Carl Folke. 2000. "Rediscovery of Traditional Ecological Knowledge as Adaptive Management.” Ecological Applications 10(5): 1251-1262.

Berlin, Brent, Dennis E. Breedlove, and Peter H. Raven. 1973. "General Principles of Classification and Nomenclature in Folk Biology." American Anthropologist 75: 214-242.

Birkeland, Charles. 1997. "Symbiosis, Fisheries and Economic Development on Coral Reefs.” Trends in Ecology \& Evolution 12(9): 364-367.

Bourke, R. Michael. 2009. "History of Agriculture in Papua New Guinea." In Food and Agriculture in Papua New Guinea, edited by R. Michael Bourke and Tracy Harwood, 10-26. Canberra, ACT: ANU E Press.

Bourke, R. Michael, and Tracy Harwood (edited by) 2009. Food and Agriculture in Papua New Guinea. Canberra, ACT: ANU E Press.

Bourke, R. Michael, John Gibson, Alan Quartermain, Kate Barclay, Bryant Allen, and Jean Kennedy. 2009. "Food Production, Consumption and Imports." In Food and Agriculture in Papua New Guinea, edited by R. Michael Bourke and Tracy Harwood, 129-192. Canberra, ACT: ANU E Press.

Bulmer, Ralph N.H. 1967. "Why is the Cassowary Not a Bird? A Problem of Zoological Taxonomy among the Karam of the New Guinea Highlands." Man (NS) 2(1): 5-25.

1982. "Traditional Conservation Practices in Papua New Guinea.” In Traditional Conservation in Papua New Guinea: Implications for Today, edited by Louise Morauta, John Pernetta, and William Heaney, 59-77. Boroko, PNG: Institute of Applied Social and Economic Research.

Büscher, Bram, Sian Sullivan, Katja Neves, Jim Igoe, and Dan Brockington. 2012. "Towards a Synthesized Critique of Neoliberal Biodiversity Conservation." Capitalism Nature Socialism 23(2): 4-30.

Caldwell, John, Bruce Missingham, and Jeff Marck. 2001. The Population of Oceania in the Second Millennium. Canberra, ACT: Health Transition Centre, Australian National University.

Cardinale, Massimiliano, Duto Nugroho, and Patrik Jonson. 2011. "Serial Depletion of Fishing Grounds in an Unregulated, Open Access Fishery." Fisheries Research 108(1): 106-111. 
Carrier, James G. 1987. "Marine Tenure and Conservation in Papua New Guinea." In The Question of the Commons: The Culture and Ecology of Communal Resources, edited by Bonnie J. McCay and James M. Acheson, 142-167. Tucson, AZ: University of Arizona Press.

Chapin, Mac. 2004. “A Challenge to Conservationists." World Watch Magazine November/December 2004: 17-31.

Cohen, Philippa, Scotta Tapala, Alik Rikio, Elton Kukiti, Frederick Sori, Zelda Hilly, Timothy J. Alexander, and Simon Foale. 2014. "Developing a Common Understanding of Taxonomy for Fisheries Management in North Vella Lavella, Solomon Islands." SPC Traditional Marine Resource Management and Knowledge Information Bulletin 33: 3-12.

Cole, Teju. 2012. "The White-Saviour Industrial Complex." The Atlantic magazine. March 21, 2012. http://www.theatlantic.com/international/ archive/2012/03/the-white-savior-industrial-complex/254843/. Retrieved 9 July 2015.

Costanza, Robert, and Herman E. Daly. 1992. "Natural Capital and Sustainable Development." Conservation Biology 6(1): 37-46.

Costanza, Robert, Ralph dArge, Rudolph deGroot, Stephen Farber, Monica Grasso, Bruce Hannon, Karin Limburg, Shahid Naeem, Robert V. Oneill, Jose Paruelo, Robert G. Raskin, Paul Sutton, and Marjan vandenBelt. 1997. "The Value of the World's Ecosystem Services and Natural Capital." Nature 387(6630): 253-260.

Cox, Paul A. 2001. "Ensuring Equitable Benefits: The Falealupo Covenant and the Isolation of Anti-Viral Drug Prostratin from a Samoan Medicinal Plant.” Pharmaceutical Biology 39: 33-40.

Curry, George N. 1999. "Markets, Social Embeddedness and Precapitalist Societies: The Case of Village Trade Stores in Papua New Guinea." Geoforum 30: 285-298.

Curry, George N., and G. Koczberski. 2012. "Relational Economies, Social Embeddedness and Valuing Labour in Agrarian Change: An Example from the Developing World.” Geographical Research 50(4): 377-392.

Curry, George, and Gina Koczberski. 2013. "Development Implications of the Engagement with Capitalism: Improving the Social Returns of Development." In Engaging with Capitalism: Cases from Oceania, edited by Fiona McCormack and Kate Barclay, 335-352. Bingley: Emerald.

Curry, George N., Gina Koczberski, Joachim Lummani, Robert Nailina, Esley Peter, Graham McNally, and Otto Kuaimba. 2015. "A Bridge Too Far? The Influence of Socio-Cultural Values on the Adaptation Responses of Smallholders to a Devastating Pest Outbreak in Cocoa." Global Environmental Change 35: 1-11.

DABFAR (Department of Agriculture: Bureau of Fisheries and Aquatic Resources). 2014. Philippine Fisheries Profile 2014. Diliman, QC: Department of Agriculture: Bureau of Fisheries and Aquatic Resources.

Dalzell, Paul, and R. A. Ganaden. 1987. "A Review of the Fisheries for Small Pelagic Fishes in Philippine waters." Philippines Bureau of Fisheries and Aquatic Resources: Technical Paper Series 10 (1). 
Dalzell, Paul, and D. Pauly. 1990. "Assessment of the Fish Resources of Southeast-Asia, with Emphasis on the Banda and Arafura Seas." "Netherlands Journal of Sea Research 25(4): 641-650.

Dalzell, Paul, P. Corpuz, F. Arce, and R. Ganaden. 1990. "Philippine Small Pelagic Fisheries and Their Management." Aquaculture and Fisheries Management 21: 77-94.

Davis, Anthony, and Kenneth Ruddle. 2010. "Constructing Confidence: Rational Skepticism and Systematic Enquiry in Local Ecological Knowledge Research.” Ecological Applications 20(3): 880-894.

Dennett, Glenn, and John Connell. 1988. "Acculturation and Health in the Highlands of Papua New Guinea. Dissent on Diversity, Diets and Development." Current Anthropology 29(2): 273-299.

Denoon, Donald. 1997. "Pacific Edens? Myths and Realities of Primitive Affluence." In The Cambridge History of the Pacific Islanders, edited by Donald Denoon, 80-118. Cambridge: Cambridge University Press.

Dowie, Mark. 2011. Conservation Refugees: The Hundred-Year Conflict between Global Conservation and Native Peoples. Cambridge, MA: The MIT Press.

Dwyer, Peter D. 1976. "Beetles, Butterflies and Bats: Species Transformation in a New Guinea Folk Classification." Oceania 46(3): 188-205.

Dyer, Michelle. 2016. "Eating Money: Narratives of Equality on Customary Land in the Context of Natural Resource Extraction Contests in the Solomon Islands." The Australian Journal of Anthropology. doi:10.1111/ taja.12213. doi: 10.1111/taja.12213.

Farmer, Paul. 2004. "An Anthropology of Structural Violence." Current Anthropology 45(3): 305-325.

Filer, Colin 1994. "The Nature of the Human Threat to Papua New Guinea's Biodiversity Endowment." In Papua New Guinea Biodiversity Country Study: The Costs and Benefits of Conserving Papua New Guinea's Biodiversity, edited by N. Sekhran and S. Miller, 187-199. Port Moresby: Papua New Guinea Department of Environment and Conservation, Conservation Resource Centre.

- 2000. "How Can Western Conservationists Talk to Melanesian Landowners about Indigenous Knowledge?" Resource Management in Asia-Pacific Working Paper No. 27. Canberra, ACT: Australian National University.

—_. 2004. "The Knowledge of Indigenous Desire: Disintegrating Conservation and Development in Papua New Guinea." In Development and Local Knowledge: New Approaches to Issues in Natural Resources Management, Conservation and Agriculture, edited by Alan Bicker, Paul Sillitoe, and Johan Pottier, 64-92. London: Routledge.

. 2011a. "Interdisciplinary Perspectives on Historical Ecology and Environmental Policy in Papua New Guinea." Environmental Conservation 38(2): 256-269. 
- 2011b. "The New Land Grab in Papua New Guinea: A Case Study from New Ireland Province." State, Society and Governance in Melanesia Discussion Papers 2011/12: 1-16.

- 2014. "The Double Movement of Immovable Property Rights in Papua New Guinea.” Journal of Pacific History 49(1): 76-94.

Filer, Colin, and Martha A. Macintyre. 2006. "Grass Roots and Deep Holes: Community Responses to Mining in Melanesia." The Contemporary Pacific 18(2): 215-231.

Filer, Colin, and Nikhil Sekhran. 1998. Loggers, Donors and Resource Owners: Policy that Works for Forests and People, edited by James Mayers, Series No. 2. Port Moresby, PNG and London: Papua New Guinea National Research Institute and International Institute for Environment and Development.

Firth, Stewart. 2006. Globalisation and Governance in the Pacific Islands. Canberra, ACT: ANU E Press.

Foale, Simon J. 1998. "What's in a Name? An Analysis of the West Nggela (Solomon Islands) Fish Taxonomy.” SPC Traditional Marine Resource Management and Knowledge Information Bulletin 9: 2-19.

—. 2001. "'Where's Our Development?' Landowner Aspirations and Environmentalist Agendas in Western Solomon Islands.” The Asia Pacific Journal of Anthropology 2(2): 44-67.

- 2005. Sharks, Sea Slugs and Skirmishes: Managing Marine and Agricultural Resources on Small, Overpopulated Islands in Milne Bay, PNG. Canberra, ACT: Resource Management in Asia Pacific Program, The Australian National University.

Foale, Simon J., and Martha A. Macintyre. 2005. "Green Fantasies: Photographic Representations of Biodiversity and Ecotourism in the Western Pacific." Journal of Political Ecology 13: 1-22.

Foale, Simon J., and Bruno Manele. 2004. "Social and Political Barriers to the Use of Marine Protected Areas for Conservation and Fishery Management in Melanesia." Asia Pacific Viewpoint 45(3): 373-386.

Foale, Simon, Philippa Cohen, Stephanie Januchowski, Amelia Wenger, and Martha Macintyre. 2011. "Tenure and Taboos: Origins and Implications for Fisheries in the Pacific." Fish and Fisheries 12(4): 357-369.

Foster, Robert J. 2005. "Commodity Futures: Labour, Love and Value." Anthropology Today 21(4): 8-12.

Gabriel, Jennifer, and Michael Wood. 2015. "The Rimbunan Hijau Group in the Forests of Papua New Guinea.” Journal of Pacific History. 50 (3): 322-343.

Gay, Daniel. 2009. Solomon Islands Diagonostic Trade Integration Study. Honiara, SI: Ministry of Foreign Affairs and External Trade.

Geertz, Clifford. 1969. "Two Types of Ecosystems." In Environment and Cultural Behaviour: Ecological Studies in Cultural Anthropology, edited by Andrew P. Vayda, 3-28. New York, NY: Natural History Press. 
Gegeo, David., and Karen Ann Watson-Gegeo. 2002. "Whose Knowledge? Epistemological Collisions in Solomon Islands Community Development." The Contemporary Pacific 14(2): 377-409.

Gehrke, Peter C. 2007. A Comparative Analysis of Coastal Fishery Food Webs in the Great Barrier Reef region. Sydney: NSW: Commonwealth Scientific and Industrial Research Organisation (CSIRO).

Goto, Akira. 1996. "Lagoon Life among the Langalanga, Malaita Island, Solomon Islands." In Coastal Foragers in Transition, edited by Tomoya Akimichi, 11-54. Osaka: National Museum of Ethnology.

Green, Alison, Paul Lokani, William Atu, Peter Ramohia, P. Thomas, and J. Almany. 2006. Solomon Islands Marine Assessment: Technical Report of Survey Conducted May 13 to June 17, 2004. Brisbane, QLD: The Nature Conservancy.

Grove, Richard H. 1990. “The Origins of Environmentalism.” Nature 345 (3 May 1990): 11-14.

Grove, Richard H. 1995. Green Imperialism: Colonial Expansion, Tropical Island Edens and the Origins of Environmentalism, 1600-1860. Cambridge: Cambridge University Press.

Helden, Flip van. 1998. Between Cash and Conviction. The Social Context of the Bismark-ramu Integrated Conservation and Development Project. Port Moresby, PNG: National Research Institute.

Henderson, C.P., and I.R. Hancock. 1988. A Guide to the Useful Plants of the Solomon Islands. Honiara, SI: Research Department, Ministry of Agriculture and Lands.

Henry, James S. 2012. The Price of Offshore Revisited. Online: Tax Justice Network. July 2012. http://www.taxjustice.net/wp-content/uploads/ 2014/04/Price_of_Offshore_Revisited_120722.pdf

Hickel, Jason, and Arsalan Khan. 2012. "The Culture of Capitalism and the Crisis of Critique.” Anthropological Quarterly 85(1): 203-227.

Hooper, D. U., F. S. Chapin, J. J. Ewel, A. Hector, P. Inchausti, S. Lavorel, J. H. Lawton, D. M. Lodge, M. Loreau, S. Naeem, B. Schmid, H. Setala, A. J. Symstad, J. Vandermeer, and D. A. Wardle. 2005. "Effects of Biodiversity on Ecosystem Functioning: A Consensus of Current Knowledge." "Ecological Monographs 75(1): 3-35.

Hviding, Edvard. 2005. Reef and Rainforest: An Environmental Encyclopedia of Marovo Lagoon, Solomon Islands / Kiladi oro vivineidi ria tingitonga pa idere oro pa goana pa Marovo, 2nd ed. Paris: UNESCO -LINKS.

- 2015. "Big Money in the Rural: Wealth and Dispossession in Western Solomons Political Economy." Journal of Pacific History 50(4): 473-485.

Hviding, Edvard, and Tim Bayliss-Smith. 2000. Islands of Rainforest: Agroforestry, Logging and Ecotourism in Solomon Islands. Aldershot: Ashgate.

Igoe, James, and Dan Brockington. 2007. "Neoliberal Conservation: A Brief Introduction." Conservation and Society 5(4): 424-470. 
Ingold, Tim. 1993. "Globes and Spheres: The Topology of Environmentalism. In Environmentalism: The View From Anthropology, edited by Kay Milton, 30-43. London: Routledge.

Jacka, Jerry. 2010. "The Spirits of Conservation: Ecology, Christianity, and

Resource Management in Highlands Papua New Guinea." Journal for the Study of Religion, Nature and Culture 4(1): 24-47.

Jackson, Tim. 2009. Prosperity without Growth: Economics for a Finite Planet. London: Earthscan.

Johannes, Robert E. 1978. "Traditional Marine Conservation Methods in Oceania and Their Demise." Annual Review of Ecology and Systematics 9: 349-364.

Johnson, Peter. 2012. Lode Shedding: A Case Study of the Economic Benefits to the Landowners, the Provincial Government and the State from the Porgera Gold Mine. Background and Financial Flows from the Mine. Port Moresby, PNG: National Research Institute.

Jolly, Margaret, Christine Stewart, and Caroline Baker 2012. Engendering Violence in Papua New Guinea. Canberra, ACT: ANU E Press.

Keppel, Gunnar, Clare Morrison, Dick Watling, Marika V. Tuiwawa, and Isaac A. Rounds. 2012. "Conservation in Tropical Pacific Island Countries: Why Most Current Approaches Are Failing." Conservation Letters 5(4): 256-265.

KIBCA (Kolombangara Biodiversity and Conservation Association). n.d. "Connections between the Environment and the Bible." Kolombangara Island, SI: Kolombangara Biodiversity and Conservation Association (unpublished Information Sheet).

Kinch, Jeff. 2006. A Socio-Economic Assessment of the Huon Coast Leatherback Turtle Nesting Beach Projects (Labu Tale, Busama, Lababia and Paiawa), Morobe Province, Papua New Guinea. Honolulu: Western Pacific Regional Fisheries Management Council.

- 2010. Integrated Coastal and Marine Resource Management in Papua New Guinea: A Review of Lessons and Best Practices. Apia, Samoa: Secretariat of the Pacific Regional Environment Program.

Kinch, Jeff, and Elizabeth A. Burgess. 2009. "An Assessment of the Trade in Hawksbill Turtles in Papua New Guinea.” TRAFFIC Bulletin 22(2): 6272.

Kirch, Patrick. 1997. "Microcosmic Histories: Island Perspectives on Global Change.” American Anthropologist 99(1): 30-42.

Kirch, Patrick V., and Douglas E. Yen. 1982. Tikopia: The Prehistory and Ecology of a Polynesian Outlier. Honolulu: Bishop Museum Press.

Koczberski, Gina, and George N. Curry. 2005. "Making a Living: Land Pressures and Changing Livelihood Strategies among Oil Palm Settlers in Papua New Guinea.” Agricultural Systems 85(3): 324-339.

Koczberski, Gina, George N. Curry, and Veronica Bue. 2012. "Oil Palm, Food Security and Adaptation among Smallholder Households in Papua New Guinea." Asia Pacific Viewpoint 53(3): 288-299. 
Kwa'iloloa, Michael, and Ben Burt. 2001. Na Masu'u kia 'i Kwara'ae [Our Forest of Kwara'ae]. London: British Museum Press.

Levinson, Stephen C. 2008. "Landscape, Seascape and the Ontology of Places on Rossel Island, Papua New Guinea." Language Sciences 30(2-3): 256290.

McCormack, Fiona, and Kate Barclay. 2013. Engaging with Capitalism: Cases From Oceania. Bingley: Emerald.

McDougall, Debra. 2005. "The Unintended Consequences of Clarification: Development, Disputing, and the Dynamics of Community in Ranongga, Solomon Islands." Ethnohistory 52(1): 81-109.

Macintyre, Martha A. 2008. "Police and Thieves, Gunmen and Drunks: Problems with Men and Problems with Society in Papua New Guinea." Australian Journal of Anthropology 19(2): 179-193.

—. 2011. "Money Changes Everything: Papua New Guinean Women in the Modern Economy." In Managing Modernity in the Western Pacific, edited by Mary Patterson and Martha Macintyre, 90-120. St. Lucia: University of Queensland Press.

- 2012. "Gender Violence in Melanesia and the Problem of Millennium Development Goal No. 3." In Engendering Violence in Papua New Guinea, edited by Margaret Jolly and Christine Stewart, 239-266. Canberra, ACT: ANU E Press.

Macintyre, Martha A., and Simon J. Foale. 2004. "Global Imperatives and Local Desires: Competing Economic and Environmental Interests in Melanesian Communities." In Globalisation and Culture Change in the Pacific Islands, edited by Victoria Lockwood, 149-164. Upper Saddle River, NJ: Pearson Prentice Hall.

- 2013. "Science, Traditional Ecological Knowledge and Anthropology: Managing the Impacts of Mining in Papua New Guinea." Collaborative Research 6: 399-418.

McKenzie, Nick, and Richard Baker. 2014. "PNG Prime Minister Peter O'Neill served with arrest warrant related to fraud allegations." Sydney Morning Herald. Sydney: Fairfax Media. June 16, 2014. http:// www.smh.com.au/world/png-prime-minister-peter-oneill-served-witharrest-warrant-related-to-fraud-allegations-20140616-3a $7 \mathrm{fm} . \mathrm{html}$.

McKenzie, Nick, Richard Baker, and John Garnaut. 2015. "Steering corrupt cash into Australia from PNG: A how-to guide." Sydney Morning Herald. June 24, 2015. http://www.smh.com.au/national/steering-corrupt-cashinto-australia-from-png-a-howto-guide-20150622-ghv1sx.html

Macpherson, Crawford Brough. 1962. "Possessive Individualism and Liberal Democracy." In The Political Theory of Possessive Individualism. Clarendon Press. Pages 46-69.

McShane, Thomas O., Paul D. Hirsch, Tran Chi Trung, Alexander N. Songorwa, Ann Kinzig, Bruno Monteferri, David Mutekanga, Hoang Van Thang, Juan Luis Dammert, Manuel Pulgar-Vidal, Meredith WelchDevine, J. Peter Brosius, Peter Coppolillo, and Sheila O'Connor. 2011. 
"Hard Choices: Making Trade-Offs between Biodiversity Conservation and Human Well-Being." Biological Conservation 144(3): 966-972.

Majnep, Ian Saem, and Ralph Bulmer. 1977. Birds of My Kalam Country. Auckland: Auckland University Press.

- 2007. Animals the Ancestors Hunted: An Account of the Wild Mammals of the Kalam Area, Papua New Guinea, edited by Robin Hide and Andrew Pawley. Adelaide, SA: Crawford House.

Martin, Keir. 2007. "Your Own Buai You Must Buy: The Ideology of Possessive Individualism in Papua New Guinea." Anthropological Forum 17(3): 285-298.

Milton, Kay. 2002. Loving Nature: Towards an Ecology of Emotion. London: Routledge.

Moore, Clive. 2008. "Pacific View: The Meaning of Governance and Politics in the Solomon Islands." Australian Journal of International Affairs 62(3): 386-407.

Mora, Camilo, Octavio Aburto-Oropeza, Arturo Ayala Bocos, Paula M. Ayotte, Stuart Banks, Andrew G. Bauman, Maria Beger, Sandra Bessudo, David J. Booth, Eran Brokovich, Andrew Brooks, Pascale Chabanet, Joshua E. Cinner, Jorge Cortés, Juan J. Cruz-Motta, Amilcar Cupul Magaña, Edward E. DeMartini, Graham J. Edgar, David A. Feary, Sebastian C. A. Ferse, Alan M. Friedlander, Kevin J. Gaston, Charlotte Gough, Nicholas A. J. Graham, Alison Green, Hector Guzman, Marah Hardt, Michel Kulbicki, Yves Letourneur, Andres López Pérez, Michel Loreau, Yossi Loya, Camilo Martinez, Ismael Mascareñas-Osorio, Tau Morove, Marc-Olivier Nadon, Yohei Nakamura, Gustavo Paredes, Nicholas V. C. Polunin, Morgan S. Pratchett, Héctor Reyes Bonilla, Fernando Rivera, Enric Sala, Stuart A. Sandin, German Soler, Rick StuartSmith, Emmanuel Tessier, Derek P. Tittensor, Mark Tupper, Paolo Usseglio, Laurent Vigliola, Laurent Wantiez, Ivor Williams, Shaun K. Wilson, and Fernando A. Zapata. 2011. "Global Human Footprint on the Linkage between Biodiversity and Ecosystem Functioning in Reef Fishes." PLoS Biol 9(4): e1000606.

Mousseau, Frédéric, and Peiley Lau. 2015. The Great Timber Heist: The Logging Industry In Papua New Guinea. Oakland, CA: Oakland Institute.

Nelson, P.N., J. Gabriel, C. Filer, M. Banabas, J. A. Sayer, G. N. Curry, G. Koczberski, and O. Venter. 2014. "Oil Palm and Deforestation in Papua New Guinea." Conservation Letters 7(3): 188-195.

Oczkowski, Autumn J., Scott W. Nixon, Stephen L. Granger, Abdel Fattah M. El-Sayed, and Richard A. McKinney. 2009. "Anthropogenic Enhancement of Egypt's Mediterranean Fishery." Proceedings of the National Academy of Sciences of the United States of America 106(5): 1364-1367.

Osmond, Meredith, Andrew Pawley, and Malcolm Ross. 2003. "The Seascape." In The Lexicon of Proto Oceanic, Vol. 2: The Physical Environment, edited by Malcolm Ross, Andrew Pawley, and Meredith Osmond, 87-113. Canberra, ACT: Pacific Linguistics. 
Palmer, Meggie. 2015. "Dirty Money: How corrupt PNG cash is reaching Australia.” Dateline: SBS. Airdate: June 23, 2015. http://www.sbs.com.au/ news/dateline/story/dirty-money-how-corrupt-png-cash-reachingaustralia.

Panoff, Francoise. 1969. "Some Facets of Maenge Horticulture." Oceania 40(1): 20-31.

Patterson, Mary, and Martha Macintyre. 2011. Managing Modernity in the Western Pacific. St Lucia: University of Queensland Press.

Peekel, P. Gerhard. 1984. Flora of the Bismarck Archipelago for Naturalists. Lae, PNG: Office of Forests, Division of Botany.

Pew Research Center. 2013. "Public's Views on Human Evolution." Online: Pew Research Center. December 30, 2013. http://www.pewforum.org/ 2013/12/30/publics-views-on-human-evolution/. Retrieved 25 July 2015.

Polanyi, Karl. 1944. The Great Transformation: The Political and Economic Origins of Our Time. Boston, MA: Beacon Press.

Polunin, Nicholas V.C. 1984. "Do Traditional Marine 'Reserves' Conserve? A View of Indonesian and New Guinean Evidence." In Maritime Institutions in the Western Pacific, edited by Kenneth Ruddle and Tomoya Akimichi, 267-283. Osaka: National Museum of Ethnology.

Porter, Doug, and Matthew Allen. 2015. "The Political Economy of the Transition from Logging to Mining in Solomon Islands.” State, Society and Governance in Melanesia Discussion Paper, Australian National University (2015/12): 16 .

Raworth, Kate. 2012. A Safe and Just Space for Humanity: Can We Live within the Doughnut? Oxford: Oxfam. https://www.oxfam.org/en/ research/safe-and-just-space-humanity.

Rist, Gilbert. 2007. "Development as a Buzzword.” Development in Practice 17(4-5): 485-491.

Robbins, J. 1995. "Dispossessing the Spirits: Christian Transformations of Desire and Ecology among the Urapmin of Papua New Guinea." Ethnology 34(3): 211-224.

- 2004. Becoming Sinners: Christianity and Moral Torment in a Papua New Guinea Society. Berkeley, CA: University of California Press.

Rockstrom, Johan, W. Steffen, K. Noone, A. Persson, F. S. Chapin, E. F. Lambin, T. M. Lenton, M. Scheffer, C. Folke, H. J. Schellnhuber, B. Nykvist, C. A. de Wit, T. Hughes, S. van der Leeuw, H. Rodhe, S. Sorlin, P. K. Snyder, R. Costanza, U. Svedin, M. Falkenmark, L. Karlberg, R. W. Corell, V. J. Fabry, J. Hansen, B. Walker, D. Liverman, K. Richardson, P. Crutzen, and J. A. Foley. 2009. "A Safe Operating Space for Humanity." Nature (London) 461(7263): 472-475.

Roeger, Jessica J. 2013. The Production of the Small Pelagic Fishery in Langalanga Lagoon, Solomon Islands, and its Contribution to Food Security. B.Sc. Honours Dissertation, School of Marine and Tropical Biology, James Cook University. 80pp.

Roeger, Jessica, Simon Foale, and Marcus Sheaves. 2016. "When 'Fishing down the Food Chain' Results in Improved Food Security: Evidence from 
a Small Pelagic Fishery in Solomon Islands." Fisheries Research 174: 250259.

Ross, Malcolm, Andrew Pawley, and Meredith Osmond. 2011. The Lexicon of Proto Oceanic: The Culture and Environment of Ancestral Oceanic Society. Vol. 4. Animals. Canberra, ACT: Pacific Linguistics, Australian National University.

Ruddle, Kenneth, and Naomichi Ishige. 2005. Fermented Fish Products in East Asia: IRMI Research Study 1. Hong Kong: International Resources Management Institute.

Russ, Garry R., and Angel C. Alcala. 2010. "Decadal-Scale Rebuilding of Predator Biomass in Philippine Marine Reserves.” Oecologia 163(4): 1103-1106.

Schmid, C. 1991. Of People and Plants: Botanical Ethnography of Nokopo Village, Madang and Morobe Provinces, Papua New Guinea. Basel: Vokerunde.

Schoeffel, Penelope. 1997. "Myths of Community Management: Sustainability, the State and Rural Development in Papua New Guinea, Solomon Islands and Vanuatu." State Society and Governance in Melanesia Discussion Paper 97/8. Canberra, ACT: Research School of Pacific and Asian Studies, Australian National University.

Seventh Day Adventist Church. 2013. Origins: Adult Sabbath School Bible Study Guide, Pacific Edition. Warburton, VIC: Signs Publishing Company. Shaxson, Nicholas. 2011. Treasure Islands: Tax Havens and the Men Who Stole the World. London: Bodley Head.

Shineberg, Dorothy. 1966. "The Sandalwood Trade in Melanesian Economics, 1841-65." Journal of Pacific History 1: 129-146.

Sillitoe, Paul. 2002. "Contested Knowledge, Contingent Classification: Animals in the Highlands of Papua New Guinea." American Anthropologist 104(4): 1162-1171.

Steadman, David W. 2006. Extinction and Biogeography of Tropical Pacific Birds. Chicago, IL and London: University of Chicago Press.

Steadman, David W., Gregory K. Pregill, and David V. Burley. 2002. "Rapid Prehistoric Extinction Of Iguanas And Birds in Polynesia." Proceedings of the National Academy of Sciences of the United States of America 99(6): 3673-3677.

Sulu, Reuben J., Hampus Eriksson, Anne-Maree Schwarz, Neil L. Andrew, Grace Orirana, Meshach Sukulu, Janet Oeta, Daykin Harohau, Stephen Sibiti, Andrew Toritela, and Douglas Beare. 2015. "Livelihoods and Fisheries Governance in a Contemporary Pacific Island Setting." PLoS ONE 10(11).

Teh, Louise S. L., Lydia C. L. Teh, and U. Rashid Sumaila. 2013. "A Global Estimate of the Number of Coral Reef Fishers.” PLoS ONE 8(6): e65397.

UNDP (United Nations Development Programme). 2014. Human Development Statistical Tables. New York, NY: UNDP. http:// hdr.undp.org/en/data, accessed 14 July 2015. 
Villanoy, Cesar L., Olivia C. Cabrera, Aletta Yniguez, Marianne Camoying, Asuncion de Guzman, Laura T. David, and Pierre Flament. 2011. "Monsoon-Driven Coastal Upwelling Off Zamboanga Peninsula, Philippines." Oceanography 24(1): 156-165.

Weng, Kevin C.M., and John R. Sibert. 1997. Analysis of the Fisheries for Two Pelagic Carangids in Hawaii. Honolulu: Joint Institute of Marine and Atmospheric Research, University of Hawaii.

West, Paige. 2006. Conservation Is Our Government Now: The Politics of Ecology in Papua New Guinea. Durham, NC and London: Duke University Press.

Wilkinson, Richard, and Kate Pickett. 2009. The Spirit Level: Why Equality is Better for Everyone. London: Penguin.

Wilson, Edward O. 1992. The Diversity of Life, new ed. London: Penguin [Original edition, 1992].

Wyatt, Nick, and David Stolper. 2013. Auspoll: Science Literacy in Australia. Canberra, ACT: Australian Academy of Science.

Simon Foale has taught anthropology at James Cook University in Townsville, Australia, since 2012. He started his career as a marine biologist, but an enduring interest in local environmental knowledge, mainly in the Pacific, as well as a desire to understand the drivers of global economic inequality, has drawn him inexorably to anthropology.

Michelle Dyer is a recent $\mathrm{PhD}$ graduate in anthropology at James Cook University in Townsville, Australia. Her research focuses on gender relations at the intersection of development and natural resource management in the Solomon Islands.

Jeff Kinch completed his anthropology PhD fieldwork on marine resource use and access in the Milne Bay Province, Papua New Guinea in 1999, and since then has been involved in marine conservation and fisheries management programmes across Melanesia and the widerPacific involving non-government organizations (NGOs), aid and donor agencies, universities and regional organizations. Jeff is currently the Principal of PNG's National Fisheries Authority's National Fisheries College and also oversees the Nago Island Mariculture and Research Facility. 